\title{
Assessment of Wind Potential in the Perspective of Water Pumping in Sahelian Area of Burkina Faso
}

\author{
Seydou Ouedraogo ${ }^{* 1}$, Komlan Lolo ${ }^{2}$, Kodjo Attipou ${ }^{2}$, Ayite Senah Akoda Ajavon ${ }^{3}$, Sonnou Tiem² \\ ${ }^{1}$ Laboratoire de Recherche en Sciences de l'Ingénieur (LARSI), Département de Génie Électrique, Institut Universitaire de \\ Technologie, Université Nazi BONI, 01 BP 1091 Bobo-Dioulasso 01, Bobo-Dioulasso, \\ Burkina Faso. \\ ${ }^{2}$ Équipe de Recherche en Mécanique (ERM), Département de Génie Mécanique, École Nationale Supérieure d’Ingénieurs \\ (ENSI), Université de Lomé, 01 BP 1515 Lomé 01, Lomé, Togo. \\ ${ }^{3}$ Laboratoire de Recherche en Sciences de l'Ingénieur (LARSI), Département de Génie Électrique, École Nationale \\ d'Ingénieurs (ENSI), Université de Lomé, 01 BP 1515 Lomé 01, Lomé, Togo.
}

\begin{abstract}
This paper focuses on the prospects for wind pumping installations in the Sahelian and Sudano-Sahelian zones of Burkina Faso. Three localities were chosen for the study namely, Dori, Ouahigouya and Ouagadougou. A statistical study allowed the determination of average wind speed. Wind speed average at the height of the tower on the three sites varies between 2.4 and $4.2 \mathrm{~m} / \mathrm{s}$. The availability of groundwater resources in the sahel, combined with the wind regime, makes it possible to determine the prospects of installing a pumping wind turbine at each site. Usable outout power of chosen wind turbine calculation made it possible to determine daily flows drawn off, using a mechanical pumping wind turbine and an aerogenerator of different nominal powers, depending on the total manometric height. The advantages and disadvantages of each pumping system are highlighted. The results show that Ouahigouya's and Ouagadougou's sites are suitable for such installations while Dori's site requires hybrid systems such as solar photovoltaic/wind or solar photovoltaic/generator.
\end{abstract}

Keywords: Livestock watering, Wind energy potential, Pumping wind turbine, Total manometric height, rate of flow

\section{INTRODUCTION}

In recent decades, marked by droughts in Sahelian countries, many pastoralists have relentlessly moved in search of water and pasture. In Burkina Faso, pastoralists and their livestock leave the Sahelian zone, considered to be the first breeding region of the country, and migrate to agricultural areas in the south, especially during the hottest months of the year [1]. The overcrowding of farm animals in the reception areas creates conflicts between farmers and herders. Furthermore, livestock occupies a strategic place in the economy of Burkina Faso. According to the Ministry of Animal Resources of Burkina Faso, livestock contributes $10 \%$ to the Gross Domestic Product and occupies the second place in value of exports after cotton. Animal husbandry is a source of income for more than $80 \%$ of the population [2]. Given the importance of the livestock sector in the national economy and social conflicts created by the migration of livestock to agricultural areas, there is an increasing urgency to address the issue of livestock water supply in the Sahel of Burkina Faso.

Field surveys show that the total demand for water for watering large herds of livestock in Burkina Faso Sahel is estimated at $72,000,000 \mathrm{~m}^{3}$ per year [3]. Watering livestock with surface water is the method most used by breeders [4]. Because of the significant potential evapotranspiration in the Sahel, surface waters of the last rainy season are quickly evaporated. In addition, Burkina Faso Sahel groundwater resources map shows that the chosen sites are characterized by the abundance of groundwater, with a tank roof ranging from 10 to 100 meters deep [5]. Several attempts have been made to make water available in the Sahel of Burkina Faso in dry season. "Christine" drilling, which pump is powered by a generator allows several hundred animals and people to access drinking water, precious and scarce during non-rainy periods [6]. However, this pumping system has experienced technical breakdowns resulting in its inoperability.

Solar, wind and biomass energy potentials in the Sahelian zone show that it is favorable to renewable energies-systems. Solar energy is mainly used in photovoltaic pumping systems for supply drinking water and for small-scale irrigation [7]. Biomass and wind energy are not exploited.

Wind energy has experienced very strong growth over the past decade, thanks to technologies development and benefits for environment [8]. Among possibilities for harnessing wind energy, there is water dewatering. Technical choice for a type of wind pumping installation on landlocked sites and distant, mainly in Sahelian and Sudano-Sahelian zones, depends on parameters such as site wind potential, water need, water point nature and distance from wind turbine to place where water should be brought [9], [10].

The main objective of this article is feasibility study of wind pumping system installation on three sites in Sahelian zone of Burkina Faso, allowing to permanently supply water to breeders and their herds. 


\section{MATERIAL AND METHOD}

For wind regime and the pumping rates study, year is divided into three periods depending on climatic specificities: dry and hot period, from March to June, rainy period from July to October and harmattan period from November to February. Study is conducted for four months, March, April, May and June, representing dry and hot periods, during which water need is highest and surface water is completely evaporated.

\section{Wind potential assessment}

For wind potential assessment, it is necessary to express wind speed frequency distribution on the site [11]. Weibull distribution is the most widely used and recommended in literature for expressing wind speed frequency distribution [12]. In Weibull distribution, wind speed variations are characterized by two functions: probability density function and cumulative distribution function [13]. Probability density function $f(v)$ indicates time fraction (or probability) for which wind have the speed $v$. It is given by equation (1).

$$
f(v)=\left(\frac{k}{c}\right)\left(\frac{v}{c}\right)^{(k-1)} \exp \left[-\left(\frac{v}{c}\right)^{k}\right]
$$

where: $\mathrm{c}$ is scale factor $(\mathrm{m} / \mathrm{s}), \mathrm{k}$ is form factor (without unit), $v$ is wind speed.

Cumulative distribution function gives time fraction (or probability) for which wind speed is less than or equal to speed $v$. Corresponding cumulative frequency is given by equation (2).

$$
F(v)=\int_{0}^{v} f(v) d v=1-\exp \left[-\left(\frac{v}{c}\right)^{k}\right]
$$

\section{Weibull parameters estimation}

There are several methods for estimating Weibull law parameters from raw wind speed data during a given period. But, power density method is the most accurate method for windy sites like those in this study [14]. Energy pattern factor $E_{P f}$ is defined by equation (3).

$$
E_{p f}=\overline{V^{3}} / \bar{V}^{3}=\frac{1}{n} \sum_{i=1}^{n} v_{i}^{3} /\left(\frac{1}{n} \sum_{i=1}^{n} v_{i}\right)^{3}
$$

where: $\bar{V}$ is the average wind speed, $n$ intervals number.

Parameter $k$ value is determined using $E_{p f}$ according to equation (4).

$$
k=1+\left(3,69 / E_{p f}^{2}\right)
$$

Then $c$ is determined with equation (5).

$$
c=\bar{V} / \Gamma(1+1 / k)
$$

where: $\Gamma$ is the gamma function defined by equation (6).

$$
\Gamma(v)=\int_{0}^{+\infty} t^{z-1} e^{t-1} d t
$$

\section{Average wind speed}

According to Weibull distribution, average wind speed $\bar{V}$ is calculated with equation (7).

$$
\bar{V}=\int_{0}^{+\infty} v f(v) d v[\mathrm{~m} / \mathrm{s}]
$$

where: $v$ is wind speed rated, $f(v)$ occurrence frequency. 


\section{Wind rose}

A wind rose allows to know, for a given point, wind frequencies observation, according to direction and force criteria [15]. Wind direction is wind origin. Winds origin is determined according to following directions: between $0^{\circ}$ and $90^{\circ}$, winds come from north-east (N-E) ; between $90^{\circ}$ and $180^{\circ}$, winds come from Southeast (S-E) ; between $180^{\circ}$ and $270^{\circ}$, winds come from southwest (S-O) ; between $270^{\circ}$ and $360^{\circ}$, winds come from northwest $(\mathrm{N}-\mathrm{O})$.

\section{Wind speed vertical extrapolation}

Wind speed data for this study are measured at 10 meters above ground. It is necessary to estimate Weibull parameters and wind speed at different altitudes [16]. Weibull parameters extrapolation is obtained by equations (8), (9) and (10).

$$
\begin{aligned}
& k_{1}=k_{0} /(1-0,00881 \times \ln (z / 10)) \\
& c_{1}=c_{0}\left(z / z_{0}\right)^{n} \\
& n=\frac{0.37-0.0088 \ln c_{0}}{1-0.0088 \ln \left(\frac{z}{10}\right)}
\end{aligned}
$$

where: $k_{0}$ is shape parameter at measurements height; $k_{l}$ shape parameter at wind turbine hub height; $\mathrm{c}_{0}$ scale parameter at measurements height; $c_{l}$ scale parameter at wind turbine hub height; $z_{0}$ measured height (10 $\left.\mathrm{m}\right)$; $z$ wind turbine hub height.

Wind speed extrapolation for different altitudes is obtained with equations (11) and (12) [16].

$$
\begin{aligned}
& v=v_{0}\left(z / z_{0}\right)^{a_{J}} \\
& \left\{\begin{array}{l}
a_{J}=1 / \ln \left(z_{g} / r_{0}\right) \\
z_{g}=\sqrt{z_{0} z}
\end{array}\right.
\end{aligned}
$$

where: $v$ is estimated velocity at height $\mathrm{z} ; v_{0}$ wind speed at measured height; $\mathrm{z}$ wind turbine hub height; $z_{0}$ measured height; $a_{J}$ empirical factor expressing surface roughness influences and atmospheric stability; $z_{g}$ geometric mean height and $r_{0}$ soil roughness.

In present study, wind speed measurements are carried out in airports and ground roughness is rural type: $r_{0}=0,07 \mathrm{~m}$ [17].

\section{Wind available power density}

Wind power density represents the amount of energy produced by wind. Power density available in wind $\left(P_{a v}\right)$, per area unit swept by wind turbine blades is given by expression (13) [18].

$$
P_{a v}=\frac{1}{2} \rho \int_{0}^{+\infty} v^{3} f(v) d v\left[\mathrm{~W} / \mathrm{m}^{2}\right]
$$

where $\rho$ is air density $\left(\mathrm{kg} / \mathrm{m}^{3}\right), v$ is wind speed, $f(v)$ probability density function.

\section{Wind recoverable power density}

According to Betz limit, the maximum wind recoverable power density $\left(P_{\text {rec }}\right)$ on a site becomes equal to $16 / 27$ of available power density. Equation (14) translates this relation [18].

$$
P_{\text {rec }}=\frac{16}{27} P_{\text {dispo }}\left[\mathrm{W} / \mathrm{m}^{2}\right]
$$

Wind recoverable energy, per area unit and for one year, according to Betz limit is expressed by equation (15).

$$
E_{r e c}=8,76 P_{r e c}\left[\mathrm{kWh} / \mathrm{m}^{2} . \mathrm{an}\right]
$$

\section{Wind turbine average power supplied}

Power provided by a wind turbine $\left(P_{u}\right)$ is given by equations (16) and (17) [18]. 


$$
\begin{cases}0 & \text { pour } v \leq V_{\text {start }} \\ a+b v^{k} & \text { pour } V_{\text {start }}\left\langlev \left\langle V_{\text {rat }}\right.\right. \\ P_{n} & \text { pour } V_{\text {rat }} \leq v<V_{\text {stop }} \\ 0 & \text { pour } v \geq V_{\text {stop }}\end{cases}
$$

with:

$a=\frac{P_{n} V_{\text {start }}^{k}}{V_{\text {start }}^{k}-V_{\text {rat }}^{k}}$ et $b=\frac{P_{n}}{V_{\text {rat }}^{k}-V_{\text {stat }}^{k}}$

where: $V_{\text {start }}$ is starting speed, $V_{\text {rat }}$ is rated speed, $V_{\text {stop }}$ is machine stop speed and $P_{n}$ is nominal power.

Electrical output power average $\left(\mathrm{P}_{\mathrm{el}}\right)$ is given by expressions (18) to (20).

$$
\begin{aligned}
& P_{e l}=\int_{0}^{\infty} P_{u s} f(v, k, c) d v \\
& P_{e l}=\int_{V_{\text {start }}}^{V_{\text {rat }}}\left(a+b v^{k}\right) f(v, k, c) d v \\
& +\int_{V_{\text {rat }}}^{V_{\text {stop }}} P_{n} f(v, k, c) d v \\
& P_{e l}=P_{n} \cdot F C
\end{aligned}
$$

Where: $V_{\text {start }}$ is starting speed, $V_{\text {rat }}$ is rated speed, $V_{\text {stop }}$ is machine stop speed and $P_{n}$ is the nominal power.

FC is factor form given by equation (21).

$$
F C=\frac{e^{-\left(\frac{V_{\text {start }}}{c}\right)^{k}}-e^{-\left(\frac{V_{\text {rat }}}{c}\right)^{k}}}{\left(\frac{V_{\text {start }}}{c}\right)^{k}-\left(\frac{V_{\text {rat }}}{c}\right)^{k}}-\left(\frac{V_{\text {stop }}}{c}\right)^{k}
$$

\section{Usable wind power}

Useful power average is related to electrical output power $P_{e l}$ by a ratio expressing transformation efficiency. Considering aerogenerator efficiency $\eta$, usable wind power average $P_{u}$ is given by equation (22).

$$
P_{u}=\eta P_{e l}
$$

Wind turbine efficiency $\eta$ is given by equations (23) and (24).

$$
\eta=\frac{P_{n}}{P_{\text {theo }}}
$$

with :

$$
P_{\text {Theo }}=\frac{1}{2} \rho_{\text {air }} S V_{\text {rat }}^{3}
$$

where: $P_{\text {heo }}$ is aerogenerator theorical power; $P_{n}$ aerogenerator nominal power; $\rho_{\text {air }}$ air density; $\mathrm{S}$ wind turbine blades surface.

\section{Pumped flow estimation}

Two pumping systems are discussed in this study namely: wind turbine mechanical pumping and wind turbine electric pumping. 


\section{Mechanical pumping}

Considering a mechanical pumping system of overall efficiency $\eta$ and total head of height $\mathrm{H}_{\mathrm{mt}}$, daily flow $Q_{d}$ is given by equation (25).

$Q_{d}=3600 \times 24 \times \frac{\eta P_{\text {meca }}}{\rho_{\text {water }} g H_{m t}}$

Where: $H_{m t}$ is total manometric height; $g$ gravity acceleration; $\rho_{\text {water }}$ water density; $\eta$ pumping system overall efficiency; and $P_{\text {meca }}$ mechanical power provided by wind.

\section{Electric pumping}

Considering an electric pumping system of overall efficiency $\eta$ and total manometric height $H_{m t}$, daily pumped water flow $Q_{\mathrm{j}}$ is given by equation (26) [19].

$$
Q_{j}=3600 \times 24 \times \frac{\eta P_{e l}}{\rho_{\text {water }} g H_{m t}}
$$

$H_{m t}$ is total manometric height; $g$ gravity acceleration; $\rho_{\text {water }}$ water density; $\eta$ pumping system overall efficiency and $P_{e l}$ electrical power.

\section{Studied sites choice}

Feasibility study covers Dori site in Northeast, Ouahigouya site in northwest and Ouagadougou site in central Burkina Faso. All sites are located in Sahelian zone of Burkina Faso, whose hot and dry climate from March to June, rainy from July to October and cold and dry from November to February is characterized by long periods of drought. In Sahel, rainfall is erratic, lasts only about 3 months and average annual rainfall is between 300 and $600 \mathrm{~mm}$. Rains poor distribution in this area has resulted in increased water requirements for livestock. Table 1 gives sites geographic coordinates.

Table 1. Studied sites geographical coordinates

\begin{tabular}{|l|l|l|l|c|}
\hline Country & \multicolumn{1}{|c|}{ Site } & \multicolumn{1}{c|}{ Longitude } & \multicolumn{1}{c|}{ Latitude } & Altitude \\
\hline \multirow{3}{*}{ Burkina Faso } & Dori & $0^{\circ} 03$ West & $14^{\circ} 03$ North & $282 \mathrm{~m}$ \\
\cline { 2 - 5 } & Ouagadougou & $1^{\circ} 32$ West & $12^{\circ} 21$ North & $299 \mathrm{~m}$ \\
\cline { 2 - 5 } & Ouahigouya & $2^{\circ} 25$ West & $13^{\circ} 35$ North & $339 \mathrm{~m}$ \\
\hline
\end{tabular}

Data used in this study are provided by Burkina Faso National Directorate of Meteorology [20]. These are results of tri-hour observations of wind force (FF_XX) and direction (DD_XX), from 0 to 24 hours and 10 meters above ground level, from the weather station of three sites (Table 1). They correspond to a collection period of 10 years, from 2004 to 2013. Data recordings are made daily, 3 hours apart, for a total of 29,224 measurements collected over ten (10) years (2004 - 2013) for each site.

\section{Pumping machines choice}

Wind energy exploitation principle in water pumping is based on kinetic energy transformation contains into mechanical energy, once in contact with wind machine blades.

For electrical pumping, mechanical energy is converted into electrical energy by alternator which supplies motor pump system installed in well. Used pump is usually centrifugal pump with asynchronous motor, which operates at variable power and speed [21].

For mechanical wind pumping, mechanical energy activates piston pump via connecting rod, mounted on rotor shaft which converts rotary motion into reciprocating rectilinear motion which controls the piston pump installed in well [22]. Starting speeds of mechanical wind turbines are order of 2.5 to $3 \mathrm{~m} / \mathrm{s}$. Converter-pump efficiency is order of $60 \%$ [23]. These wind turbines are generally equipped with propeller and whose diameters can reach 9 meters. However, because of mechanical stress, stem can not exceed heights of 20 meters. This type of installation is reserved for wells whose depth is less than 15 meters [23]. 


\section{RESULTS AND DISCUSSIONS}

Figure 1 shows wind speed measured distribution at Dori, Ouahigouya and Ouagadougou sites.
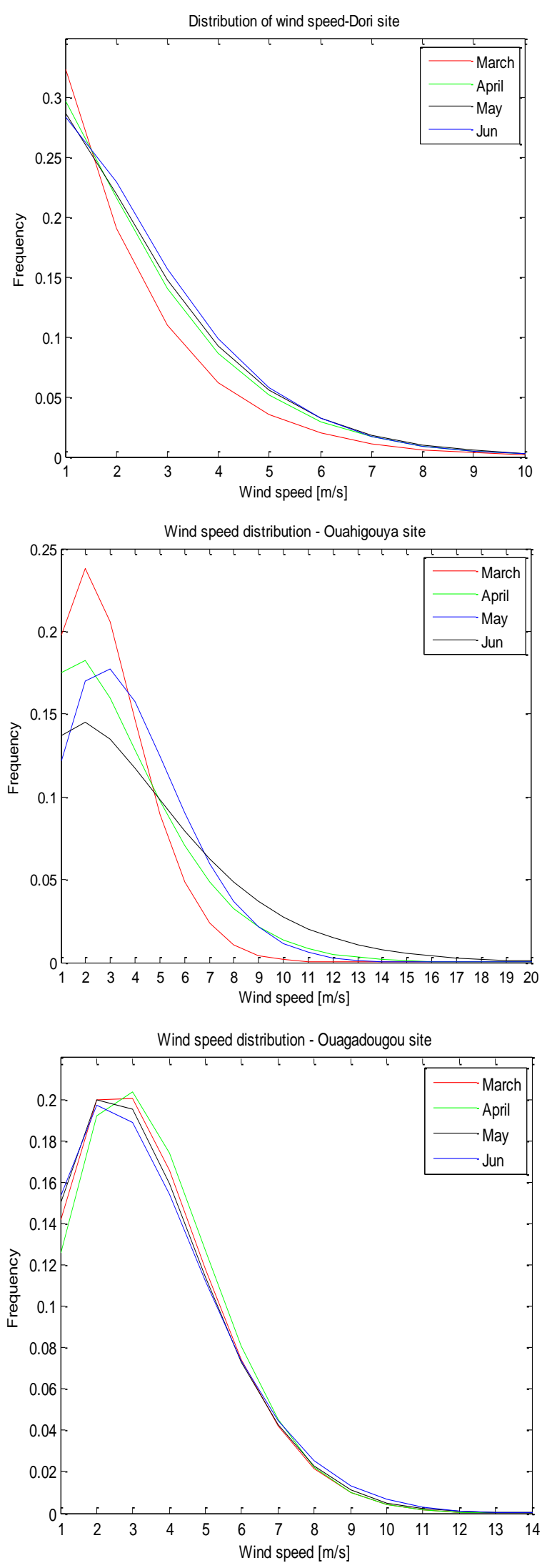

Figure 1. Wind speed dsitibution at the three sites. 
Observation in figure 1 is that calm winds (speed less than $1 \mathrm{~m} / \mathrm{s}$ ) are frequent on three sites. Calm winds frequency is 0.35 for Dori site, 0.20 for Ouahigouya site and 0.15 for Ouagadougou site. Considering the frequency of calm winds, Ouagadougou site has the best wind distribution among three studied sites. Weibull's distribution shows that studied sites are not enough windy. Table 2 shows Weibull shape and scale parameters monthly variation, estimated by power density method, for studied sites.

Table 2. Estimated shape and scale factors monthly by power density method

\begin{tabular}{|l|l|l|l|l|l|l|}
\hline \multicolumn{2}{|c|}{ Site } & \multicolumn{2}{|c|}{ Dori } & \multicolumn{2}{c|}{ Ouagadougou } & \multicolumn{2}{c|}{ Ouahigouya } \\
\hline Month & \multicolumn{1}{c|}{$\mathrm{c}[\mathrm{-}]$} & $\mathrm{k} / \mathrm{m} / \mathrm{s}]$ & $\mathrm{c}[\mathrm{m} / \mathrm{s}]$ & $\mathrm{k}[-]$ & $\mathrm{c}[\mathrm{m} / \mathrm{s}]$ \\
\hline March & 1.0380 & 1.8432 & 1.8031 & 3.9067 & 1.6922 & 3.2770 \\
\hline April & 1.1933 & 2.3711 & 1.8932 & 4.0377 & 1.3981 & 3.9846 \\
\hline May & 1.2369 & 2.5159 & 1.7343 & 3.8825 & 1.7410 & 4.4263 \\
\hline Jun & 1.3024 & 2.5615 & 1.6798 & 3.9115 & 1.3323 & 5.0467 \\
\hline
\end{tabular}

Observation is that shape parameter k varies between 1.038 in Dori (in March) and 1.8932 in Ouagadougou (in April). So, wind speed is more uniform in Ouagadougou during April month, while it is less uniform in Dori during March month. Scale parameter c varies between $1.8432 \mathrm{~m} / \mathrm{s}$ in Dori (in March) and $5.0467 \mathrm{~m} / \mathrm{s}$ in Ouahigouya (in June), which shows that Ouahigouya site is windiest for this period. Monthly wind speeds average at $10 \mathrm{~m}$ height at three sites are shown in figure 2.



Figure 2. Monthly wind speed average at $10 \mathrm{~m}$ height at three sites.

Wind speed has $4.63 \mathrm{~m} / \mathrm{s}$ maximum value in Ouahigouya site (in June), while minimum wind speed of $1.26 \mathrm{~m} / \mathrm{s}$ is recorded in November in Dori site. For Dori site, monthly wind speed averages are below $2.5 \mathrm{~m} / \mathrm{s}$. Ouagadougou site presents practically constant monthly speed averages, around $3.5 \mathrm{~m} / \mathrm{s}$. At Ouahigouya site, monthly speeds averages vary from $2.20 \mathrm{~m} / \mathrm{s}$ in November to $4.63 \mathrm{~m} / \mathrm{s}$ in June. Studied sites are not sufficiently windy.

\section{Wind roses}

Wind roses at Dori, Ouahigouya and Ouagadougou sites are shown in figure 3.



a)



b) 


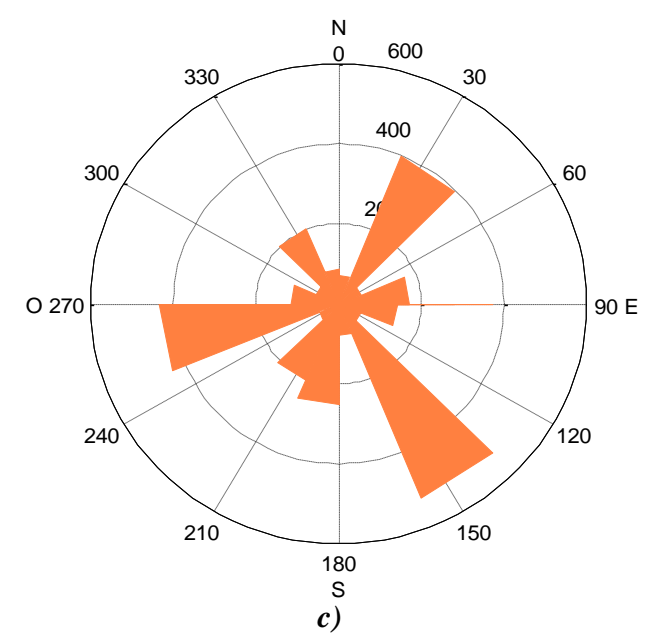

Figure 3. Wind roses at three studies sites: a) at Dori site, b) at Ouahigouya site, c) at Ouagadougou site

Wind statistics observation and analysis show predominance in direction: Northeast, with an inclination to North of geometric angle in third sector (between $60^{\circ}$ and $90^{\circ}$ ) for Dori's site; Southeast, with an inclination to North of geometric angle varying between fifth and sixth sector (between $120^{\circ}$ and $180^{\circ}$ ) for Ouagadougou's site; South West, with an inclination to North of geometric angle being in ninth sector (between $240^{\circ}$ and $270^{\circ}$ ) for Ouahigouya's site. Annual speed averages are evaluated at 10 $\mathrm{m}$ to $130 \mathrm{~m}$ heights in $10 \mathrm{~m}$ steps, with soil roughness $r_{0}=0.07 \mathrm{~m}$. Figure 4 shows extrapolated wind speeds.

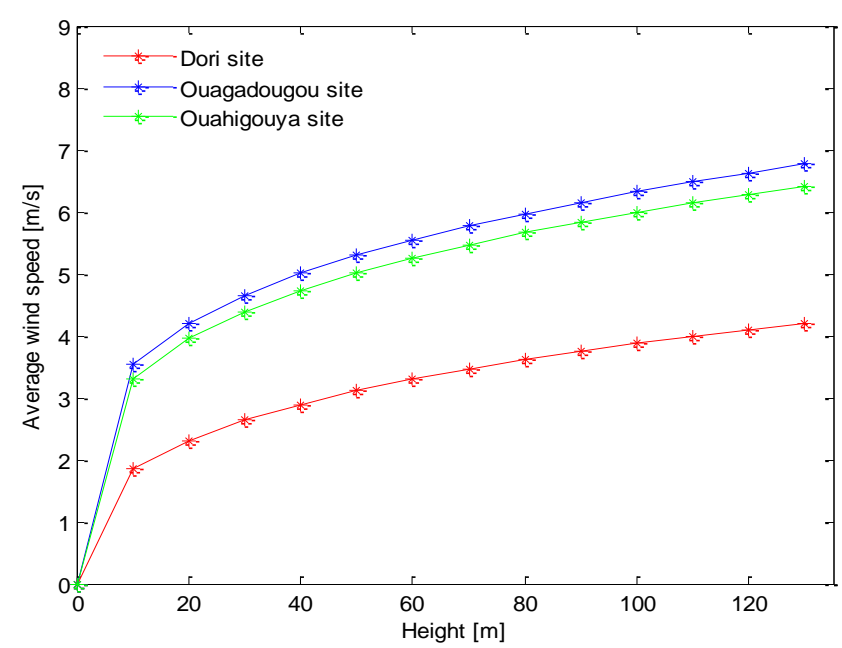

Figure 4. Annual average wind speed at different height at three sites.

We notice that at $60 \mathrm{~m}$ height, minimum annual average wind speed of $3.29 \mathrm{~m} / \mathrm{s}$ is recorded at Dori, while average annual maximum speed of $5.54 \mathrm{~m} / \mathrm{s}$ is recorded in Ouagadougou. Annual speed average in Ouahigouya is $5.25 \mathrm{~m} / \mathrm{s}$. At $130 \mathrm{~m}$ height, wind speed annual minimum average of $4.20 \mathrm{~m} / \mathrm{s}$ is recorded at Dori, while speed annual maximum average of $6.76 \mathrm{~m} / \mathrm{s}$ is recorded in Ouagadougou. Wind speed annual average in Ouahigouya is $6.39 \mathrm{~m} / \mathrm{s}$. From $60 \mathrm{~m}$ height, Ouagadougou and Ouahigouya sites have wind speed average higher than $5 \mathrm{~m} / \mathrm{s}$, which is sufficient for interesting electricity production with wind turbines. But for Dori site, it is necessary to go beyond $130 \mathrm{~m}$ height to obtain wind speeds greater than $5 \mathrm{~m} / \mathrm{s}$. Figure 5 shows recoverable power density at three studied sites. 




Figure 5. Recoverable wind power density at three studies sites

Three commercial wind turbines of nominal power equal to $3.5,10$ and $35 \mathrm{~kW}$ were chosen for the simulation of electric pumping. Figure 6 represents useful and usable power for $10 \mathrm{~kW}$ wind turbine, respectively at Dori, Ouahigouya and Ouagadougou sites.


Figure 6. Useful and usable power of wind turbine at three studies sites 
Water flow rates pumped by aerogenerator vary according to three sites and periods of year. Factors influencing water flow are highlighted in results summarized in tables 3 to 5, respectively for Dori, Ouahigouya and Ouagadougou sites.

Table 3. Pumping rates variation according to influencing factors at Dori site

\begin{tabular}{|c|c|c|c|c|c|}
\hline \multirow{2}{*}{$\begin{array}{c}\text { Total manometric height } \\
\mathrm{H}_{\mathrm{mt}}(\mathrm{m})\end{array}$} & $\begin{array}{c}\text { Wind turbine tower } \\
\text { height } \\
\mathrm{H}(\mathrm{m})\end{array}$ & \multicolumn{4}{|c|}{ Daily water volume pumped $\left(\mathrm{m}^{3}\right)$} \\
\cline { 3 - 6 } & 20 & March & April & May & Jun \\
\cline { 3 - 6 } & 25 & 0.0175 & 0.0226 & 0.0260 & 0.0225 \\
\cline { 2 - 6 } & 20 & 0.0225 & 0.0275 & 0.0325 & 0.0274 \\
\cline { 2 - 6 } & 30 & 0.0255 & 0.0350 & 0.0375 & 0.0350 \\
\hline \multirow{3}{*}{30} & 20 & 0.0150 & 0.0200 & 0.0225 & 0.0195 \\
\cline { 2 - 6 } & 25 & 0.0175 & 0.0226 & 0.0250 & 0.0226 \\
\hline
\end{tabular}

Table 4. Pumping rates variation according to influencing factors at Ouahigouya site

\begin{tabular}{|c|c|c|c|c|c|}
\hline \multirow{3}{*}{$\begin{array}{l}\text { Total manometric height } \\
\qquad \mathrm{H}_{\mathrm{mt}}(\mathrm{m})\end{array}$} & \multirow{3}{*}{$\begin{array}{c}\text { Wind turbine tower } \\
\text { height } \\
\mathrm{H}(\mathrm{m})\end{array}$} & \multicolumn{4}{|c|}{ Daily water volume pumped $\left(\mathrm{m}^{3}\right)$} \\
\hline & & \multicolumn{4}{|c|}{ Ouahigouya site } \\
\hline & & Mars & Avril & Mai & Juin \\
\hline \multirow{3}{*}{20} & 20 & 0.05 & 0.09 & 1.45 & 2.70 \\
\hline & 25 & 0.05 & 0.09 & 1.70 & 3.00 \\
\hline & 30 & 0.05 & 0.10 & 2.00 & 3.20 \\
\hline \multirow{3}{*}{30} & 20 & 0.02 & 0.05 & 0.30 & 0.55 \\
\hline & 25 & 0.025 & 0.05 & 0.35 & 0.60 \\
\hline & 30 & 0.025 & 0.075 & 0.4 & 0.65 \\
\hline
\end{tabular}

Tableau 5 Pumping rates variation according to influencing factors at Ouagadougou site

\begin{tabular}{|c|c|c|c|c|c|}
\hline \multirow{3}{*}{$\begin{array}{l}\text { Total manometric height } \\
\qquad \mathrm{H}_{\mathrm{mt}}(\mathrm{m})\end{array}$} & \multirow{3}{*}{$\begin{array}{c}\text { Wind turbine tower } \\
\text { height } \\
\mathrm{H}(\mathrm{m})\end{array}$} & \multicolumn{4}{|c|}{ Daily water volume pumped $\left(\mathrm{m}^{3}\right)$} \\
\hline & & \multicolumn{4}{|c|}{ Ouagadougou site } \\
\hline & & Mars & Avril & Mai & Juin \\
\hline \multirow{3}{*}{20} & 20 & 0.050 & 0.050 & 0.96 & 1.05 \\
\hline & 25 & 0.050 & 0.050 & 1.110 & 1.275 \\
\hline & 30 & 0.090 & 0.090 & 1.375 & 1.500 \\
\hline \multirow{3}{*}{30} & 20 & 0.028 & 0.028 & 0.190 & 0.200 \\
\hline & 25 & 0.030 & 0.030 & 0.230 & 0.250 \\
\hline & 30 & 0.070 & 0.070 & 0.275 & 0.300 \\
\hline
\end{tabular}

Tables 3, 4 and 5 results snalysis shows site influence. We notice that for same period, same total manometric height and wind turbine tower height, daily flows obtained at Dori site for June month $\left(0.0225 \mathrm{~m}^{3}\right)$ are low, compared to those obtained at Ouahigouya and Ouagadougou sites which are respectively $2.70 \mathrm{~m}^{3}$ and $1.05 \mathrm{~m}^{3}$. This is explained by low wind potential at first site.

We note that, for Ouahigouya and Ouagadougou sites, water volumes pumped in June, with different total manometric heights and various wind tower heights are always high compared to those obtained in other months. This is explained by daily wind speeds average levels observed during June month of each year on these sites. For Dori site, May is month with the highest water pumped volumes compared to those obtained in other months.

Total manometric heights increase negatively affects water volumes pumped, whatever site and wind turbine height. Figure 7 illustrates well pumped flows decrease curves, according to total manometric height, corresponding to hottest periods of year, from March to June at three sites. 

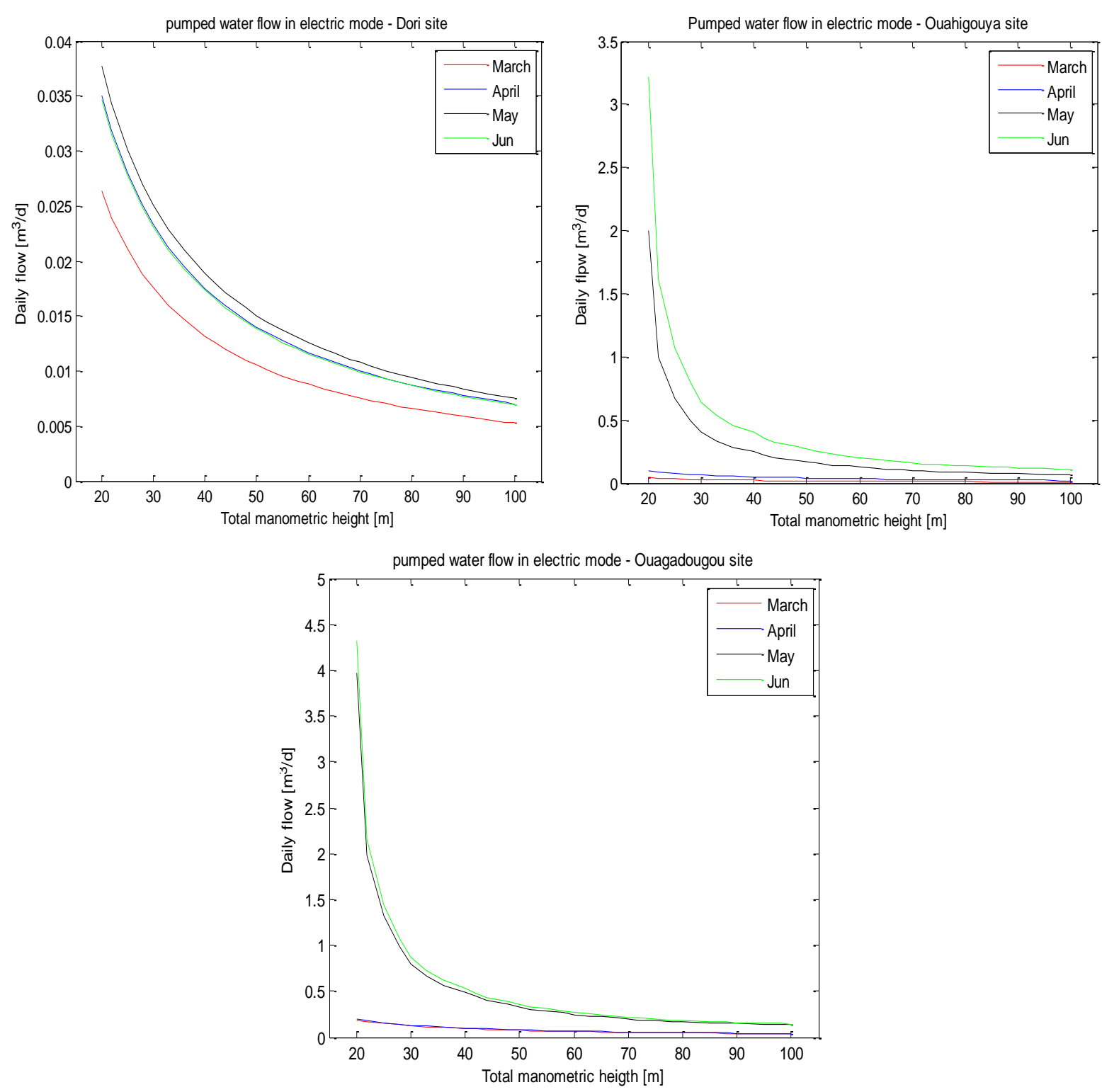

Figure 7. Pumped water flow in electric mode at three sites.

As an indication, for Ouahigouya site, in June, daily flow which was $2.70 \mathrm{~m}^{3}$, for $20 \mathrm{~m}$ total manometric height, drops to 0.55 $\mathrm{m}^{3}$, when manometric height increases by $10 \mathrm{~m}$.

Generally, wind turbines have various heights of pylon. For selected wind turbine for this study, it can be mounted at three different pylon heights: $20 \mathrm{~m}, 25 \mathrm{~m}$ or $30 \mathrm{~m}$. Pylon height influence is highlighted by tables 3,4 and 5 results. By setting total manometric height at three sites, we see, that increasing wind turbine pylon height translates into increase in water flows pumped. For example, for Ouagadougou site, with $20 \mathrm{~m}$ total manometric height and $20 \mathrm{~m}$ elevation of machine propeller, flow is $0.96 \mathrm{~m}^{3}$ in May, whereas it increases to $1.315 \mathrm{~m}^{3}$, when height becomes $30 \mathrm{~m}$; or $27 \%$ gain in flow for $10 \mathrm{~m}$ difference in height.

Mechanical pumping simulation is done with machines of similar power to wind turbines used in electric mode. Simulation results with a $10 \mathrm{~kW}$ power wind turbine, during hot season, from March to June are shown in figures 8 . 

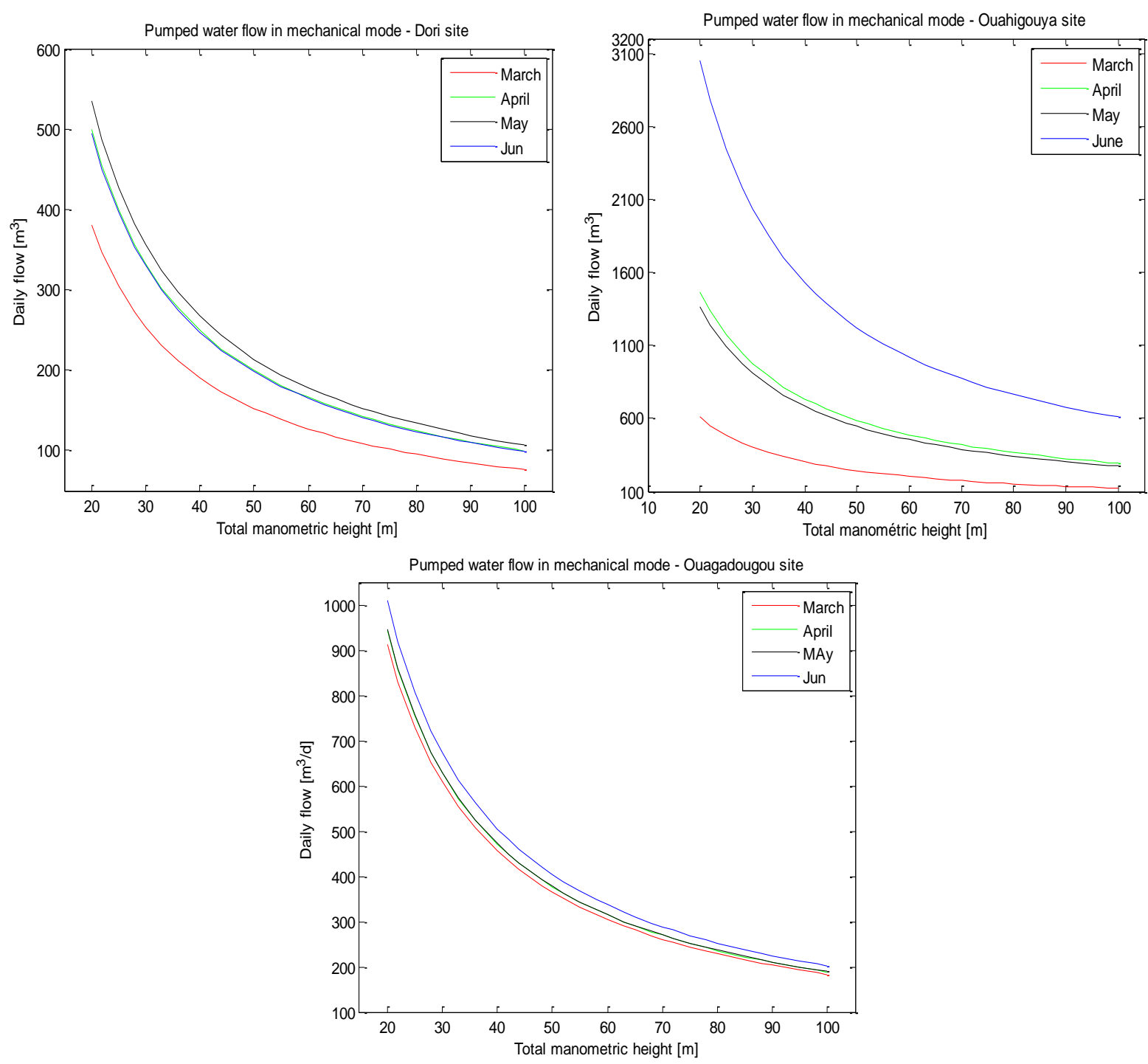

Figure 8. Pumped water flow in mechanical mode at three sites

Different curves examination shows that pumped flows are more important in mechanical mode than by electric mode. But well depth constraints of less than $35 \mathrm{~m}$, penalize the mechanical pumping mode. Pumped flows with large wind turbines are more important and offer great possibilities. However, the wind regimes on studied sites mean that, to obtain pumped water flows comparable to those of mechanical mode, it would require large wind turbines, for tower heights up to $130 \mathrm{~m}$.

\section{CONCLUSION}

Wind energy potentials study on installation sites went through wind data statistical processing, which allowed available wind potential assessment. Really usable wind potential was used to estimate daily flow rates pumped for several total manometric height. For electric pumping, daily flow average estimation, according to total manometric height pumping was carried out considering three commercial wind turbines characteristics, supposedly installed on three Sahelian sites, namely, Dori, Ouahigouya and Ouagadougou. Results showed that, across all three sites studied, water flows pumped in electric mode are low, compared to livestock water requirement. Same study was made considering mechanical pumping mode and taking into account limits of system. It has been observed that pumped water flows are greater in mechanical mode than in electric mode.

Ouahigouya and Ouagadougou sites can well house wind pumping installations. However, for Dori site, wind pumping is not efficient. For Dori site, we recommand use of other renewable energies in combination with wind energy, such as: photovoltaic solar energy and biogas produced from livestock waste, used as gaseous fuel in generators. Similarity of studied problem in several areas of Burkina Faso, require that solution approach developed, be applied to all farming areas of Burkina Faso and in Africa Sahelian area. 
The authors want to thank the University Nazi BONI and the University of Lomé for providing enabling environment during the research.

\section{REFERENCES}

[1] Ministère de l'environnement et de l'eau, "État des lieux des ressources en eau du Burkina Faso et de leur cadre de gestion", Ouagadougou, Burkina Faso, 2001.

[2] Ministère des Ressources Animales, "Plan d'actions et programme d'investissements du secteur de l'élevage au Burkina Faso", Ouagadougou, Burkina Faso, 2000.

[3] DREA Direction régionale de l'Eau et de l'Assainissement du Sahel, "La problématique de l'eau souterraine dans le sahel burkinabè", Ouagadougou, Burkina Faso, 2019.

[4] L. Ouedraogo, B. Ouedraogo, O. Kaboré, P. I. Yanogo, T. P. Zoungrana et I. B. MoussA, "Localisation des zones d'accès à l'eau en saison sèche par analyse multicritère dans le bassin versant du Goudébo, Yakouta, Burkina Faso", in Revue Physio-Géo, vol. 7(2013), pp. 49-66, 2013.

[5] N-D. Yameogo, N. Kibi et T. Thiombiano, "Analyse socio-économétrique de la demande d'eau et de pâturage pour le bétail : cas du département de Loumbila au Burkina Faso", Rapport, Université de Ouagadougou, Burkina Faso, 2002.

[6] K. A. Karama, "Elevage dans le Sahel : 'Christine' ou le symbole de l'hydraulique pastorale", éditions Sidwaya, Mai 2009.

[7] C. Pezon, Fabrice Agognon, Richard Bassono, "Coût, performance et régulation des petits réseaux de distribution d'eau potable au Burkina Faso Étude de six AEPS dans la région du Sahel", hal-02012147, 2013.

[8] R. Maouedj, S. Bousalem et B. Benyoucef, "Optimisation d'un système de pompage éolien : Application aux sites sahariens", in Revue des Energies Renouvelables, vol. 11, no 2, p. $239-250,2008$.

[9] S. Ouedraogo, A. S. A. Ajavon, A. A. Salami, M. K. Kodjo, and K-S. Bédja, "Evaluation of wind potential in the sahelian area: case of three sites in Burkina Faso", in Research Journal of Engineering Sciences vol. 6, Issue 11, p. 43-53, 2017.

[10] B. Bambara, "Atlas des énergies renouvelables du Burkina Faso", Mémoire de master, Institut International d’Ingénierie, Ouagadougou - Burkina Faso, 27 Octobre 2015.

[11] A. Mostafaeipour, M. Jadidi, K. Mohammadi and A. Sedaghat, "An Analysis of Wind Energy Potential and Economic Evaluation in Zahedan, Iran", in Renewable and Sustainable Energy Reviews, Vol. 30, p. 641-650, 2014.

[12] B. Safari, "Modeling wind speed and wind power distributions in Rwanda", in Renewable and Sustainable Energy Reviews, vol. 15, no 2, p. 925935, 2011.

[13] D. K. Kidmo, R. Danwe, S. Y. Doka and N. Djongyang, "Statistical analysis of wind speed distribution based on six Weibull Methods for wind power evaluation in Garoua, Cameroon", in Revue des Energies Renouvelables, vol. 18, no 1, p. 105-125, 2015.

[14] M. A. Houekpoheha, B. Kounouhewa, B. N. Tokpohozin and N. Awanou, "Estimation de la puissance énergétique éolienne à partir de la distribution de Weibull sur la côte béninoise à Cotonou dans le Golfe de Guinée", in Revue des Energies Renouvelables, vol. 17, no 3, p. 489-495, 2014.

[15] M. Abdraman, A. Tahir, D. Lissouck, M. Kazet and R. Mouangue, "Wind Resource Assessment in the City of N'djamena in Chad", in Internationa Journal of Renewable Energy Research (IJRER), vol. 6, no 3, p. 1022-1036, 2016.

[16] Drissa BORO, Willy Magloire NKOUNGA, Mouhamadou Falilou NDIAYE, MamadouLamine NDIAYE, Florent P. KIENO \& Joseph D. BATHIEBO, "Statistical analysis of wind data and assessment of wind potential in BurkinaFaso", IJESRT, vol. 8, Issue 2, February 2019.

[17] S. Ouedraogo, A. S. A. Ajavon, A. A. Salami, M. K. Kodjo, "Optimality sizing of hybrid electrical power plant composed of photovoltaic generator, wind generator and biogas generator", in Research Journal of Engineering Sciences, vol. 7, Issue 11, p. 20-53, 2018.

[18] G. Al Zohbi, P. Hendrick et P. Bouillard, "Evaluation du potentiel d'énergie éolienne au Liban", in Revue des énergies renouvelables, vol. 17, no 1, p. $83-96,2014$

[19] N. K. Merzouk, M. Merzouk et B. Benyoucef, "Perspectives du pompage éolien dans le sud algerien", Algerian Scientific Journal Plateform, vol. 1, no 17, p. 27-37, 2015.

[20] Direction Générale de la Météorologie du Burkina Faso, "Données climatologiques de stations météorologiques (2004-2013)", Standards and Reports, Ouagadougou, Burkina Faso, 2015.

[21] A. Adjiri, H. Daaou Nedjari et S. Haddouche, "Estimation du potentiel éolien pour la région d'In Salah", in Revue des Energies Renouvelables, vol 16, no 4, p. $657-666,2013$.

[22] S. Baillargeon, "Les-éoliennes-de-pompage", Récupéré de http://www.economiesolidaire.com/les-eoliennes-de-pompage, 2019.

[23] M. Benabdelkader, A. Malek et B. Draoui, "Perspective du pompage éolien appliqué à l'irrigation du palmier dattier dans la région de Béchar", in Revue des Energies Renouvelables, vol. 14, no 3, p. 381 - 395, 2011 